\title{
Seasonal variations of pico- and nano-detrital particles (DAPI Yellow Particles, DYP) in the Ligurian Sea (NW Mediterranean)
}

\author{
Behzad Mostajir*, John R. Dolan, Fereidoun Rassoulzadegan \\ Université P. \& M. Curie (Paris VI), Station Zoologique, URA-CNRS 716, BP 28, F-06230 Villefranche-sur-Mer, France
}

\begin{abstract}
Seasonal variations of pico- and nano-sized marine detrital particles (DAPI Yellow Particles, DYP) and their relationships with components of the microbial food web were studied from April 1993 to March 1994 in the NW Mediterranean Sea. A hierarchical flexible clustering distinguished 2 major groups of DYP: $\leq 10 \mu \mathrm{m}$ and $10-20 \mu \mathrm{m}$. Average abundance and total surface area of $\leq 10 \mu \mathrm{m}$ DYP in surface waters were $21.6 \pm 3.2 \times 10^{6} \mathrm{l}^{-1}$ and $153 \pm 55 \mathrm{~mm}^{2} \mathrm{l}^{-1}$, respectively, approximately an order of magnitude greater than abundances or total surface areas reported for larger detrital particles. Relationships of DYP, chlorophyll a and micro-organisms were investigated within and among 5 different hydrographic periods distinguished via vertical temperature gradients. Peak concentrations of $\leq 10 \mu \mathrm{m}$ DYP occurred in early autumn at the end of stratification. In contrast, DYP 10-20 $\mu \mathrm{m}$ peaked at the beginning of the stratification period in early June. Correlation analysis revealed only weak relationships between DYP and abundance of bacteria, heterotrophic microflagellates and ciliates. However, declines in chlorophyll were generally followed by increases in DYP concentrations.
\end{abstract}

KEY WORDS: Detrital particles · Detritus - DAPI Yellow Particles (DYP) - Microbial populations Mediterranean Sea

\section{INTRODUCTION}

The role of large detrital particles in oceanic biogeochemistry is quite well studied (Fowler \& Knauer 1986). In contrast, small detrital particles have received little attention. The lack of simple methods of observing pico- and nano-sized detrital particles has likely hampered studies of these size fractions of detrital particles. However, some general trends were established in the 1960s in studies which considered particles down to the micro- and nano-size range.

Riley (1963) found a bimodal seasonal cycle of organic aggregates ( $5 \mu \mathrm{m}$ to several $\mathrm{mm}$ ) with peaks in winter and early summer which he related to the phytoplankton population in Long Island Sound, USA. Riley et al. (1964) showed the same phenomenon between Bermuda and the west coast of Africa. Later, Riley et al. (1965) observed that numbers of organic

\footnotetext{
•E-mail: microbe@ccrv.obs-vlfr.fr
}

aggregates ( $5 \mu \mathrm{m}$ to several $\mathrm{mm}$ ) in surface waters of the Sargasso Sea were relatively small at all times but showed a slight seasonal variation, with highest values in winter and spring and lower ones in summer, in general agreement with the observed seasonal variations in phytoplankton. Kane (1967) followed the seasonal variations of organic aggregates in the Ligurian Sea (NW Mediterranean). Her data indicated a similar variation of detritus $(10-260 \mu \mathrm{m})$ as found by Riley and his co-workers, in good agreement with phytoplankton variations. These studies all suggested, by grouping all particle size-classes together, that detrital particles are a homogenous pool and are closely linked with phytoplankton stocks. However, quantification of the stocks of pico- and nano-sized particles separately is of importance because they represent non-living organic matter with low to negligible sinking velocities.

In the companion paper we present a rapid method for the quantification of pico- and nano-detrital particles (Mostajir et al. 1995). Using the DAPI (4'6'-diamidino-2-phenylindole) stain, epifluorescence counts 
of DAPI Yellow Particles, DYP, can be made, particles without the characteristic blue fluorescence of DAPI conjugated with DNA rich in A-T base pairs. We showed that more than $90 \%$ of DYP are almost exclusively organic, enzyme-degradable matter and that they represent an abundant class of degradable organic particles. Preliminary data indicated that DYP were distributed very irregularly with depth along an offshore transect in the Ligurian Sea (Mostajir et al. 1995) suggesting that DYP represent a highly dynamic stock of particulate matter.

In the present paper we present data on pico- and nano-sized DYP detrital particles based on weekly sampling over 1 yr in the Ligurian Sea. Relationships among different size classes of pico- and nano-DYP were examined and stocks are compared to those of living particles in the microbial loop, and chlorophyll a (chl a) in distinct periods defined by water column structure. We were interested in examining the relationship of DYP stocks to chl a and determining whether periods in which DYP are abundant correspond with periods of high heterotrophic microbial biomass.

\section{MATERIALS AND METHODS}

Sampling. The study site, Point ' $\mathrm{B}$ ', is a standard oceanographic station at the entrance of Villefranche Bay $\left[43^{\circ} 41^{\prime} 10^{\prime \prime} N, 7^{\circ} 19^{\prime} 00^{\prime \prime} \mathrm{E}\right.$; see Etienne et al. (1991) for site background]. Samples were taken once a week from March 31, 1993, to March 30, 1994 Temperature was measured with a Seabird CTD at 0, 10, 20, 30,40, 50,60 and $75 \mathrm{~m}$. Using Niskin bottles, samples for chl a analysis were taken from $0,10,20,30,50$ and $75 \mathrm{~m}$. For enumeration of DYP and micro-organisms, samples were taken from 4 standard depths chosen to correspond with surface waters, the summer thermocline, the average depth of the chlorophyll maximum and deep water: 0, 20,40 and $75 \mathrm{~m}$.

Sample processing. Chl a was analysed following the protocols of SCOR/UNESCO (1964). DYP enumeration procedures are given in Mostajir et al. (1995) Briefly, $10 \mathrm{ml}$ water samples were fixed with formalin ( $3 \%$ final conc.), stained with DAPI (final conc $0.25 \mu \mathrm{g} \mathrm{ml} \mathrm{m}^{-1}$ ) and immediately drawn down onto a $25 \mathrm{~mm}$ black Nuclepore polycarbonate membrane (0.2 $\mathrm{mm}$ pore size) using low vacuum (<0.2 bar). The filter was placed on a slide, and examined with an epifluorescence microscope with a $100 \times$ Neofluar objective. Particles were enumerated in size classes of $0.2-2,2-5,5-10,10-15$ and $15-20 \mu \mathrm{m}$. For each size class, 100 pico- and nano-DYP were counted. To calculate the surface area of particles they were considered as circles with diameters as follows for each of the above size classes, respectively: $1.25,3.5,7.5,12.5$ and $17.5 \mu \mathrm{m}$. The precision of particle counting is reported in Mostajir et al. (1995). The standard error as a percentage of the mean, ranges from 3 to $66 \%$ with the relative error increasing with particle size class. On the same filters prepared for DYP counts, heterotrophic microorganisms, flagellates and bacteria were counted. Estimates of ciliate microzooplankton were made from $100 \mathrm{ml}$ of sample water, preserved with acid Lugol (0.4\% final concentration), sedimented for $24 \mathrm{~h}$ and examined with a Zeiss inverted microscope.

Data analysis. Characterisation of hydrographic conditions: Hydrographic periods were distinguished based on temperature differences between 0 and $75 \mathrm{~m}$ $(\Delta t)$, similar to the procedure of Bustillos-Guzmán et al. (1995), used for the same site. A $M I X+$ period was defined as positive $\Delta t$ (deep layers were colder than surface waters) which occurred in early spring, from March 31 to April 29, 1993. Following this period, stratification of the water column began and the stratified period was divided into 3 subdivisions: SEMI+ (semistratified+), a period of rapid increase in surface water temperature (from May to early June), STRATIFIED

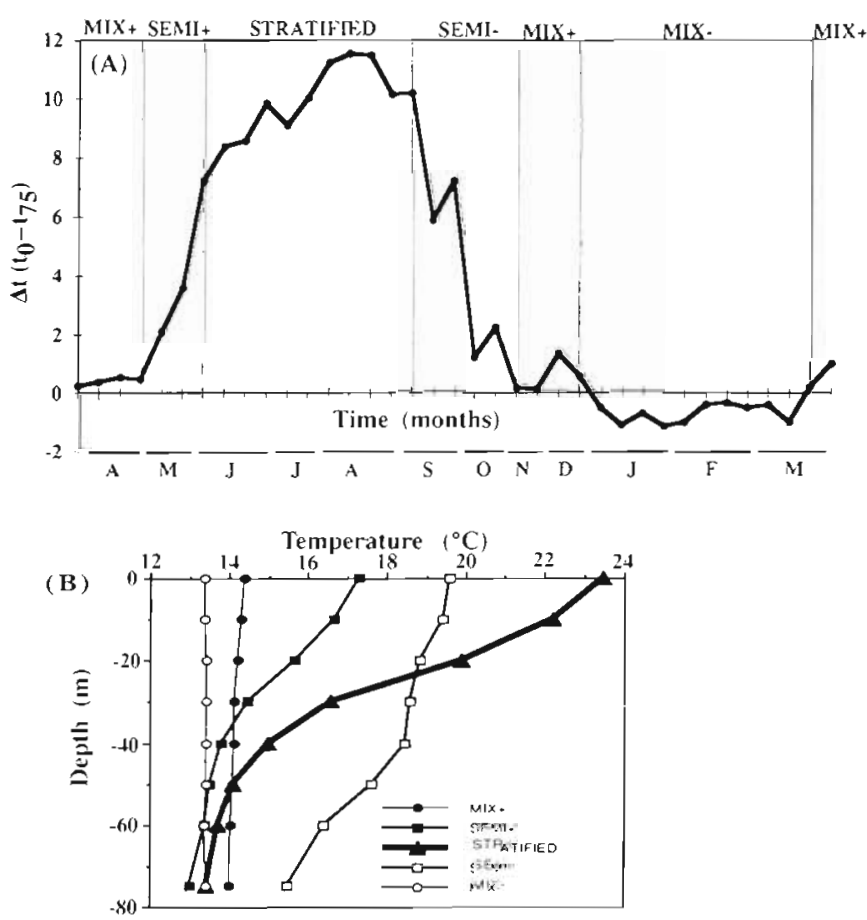

Fig. 1. (A) Seasonal temperature variations $(\Delta t)$ at Pount 'B', a standard oceanographical station at the mouth of Villefranche Bay $\left(43^{\circ} 41^{\prime} 10^{\prime \prime} N, 7^{\circ} 19^{\prime} 00^{\prime \prime}\right.$ E) from March 31, 1993 to March 30, 1994. Different hydrographic periods are indicated. (B) Vertical profile of temperature at different hydrographic conditions in 1993. Each point is the mean of all data for each period in each depth 
(from June to September) and SEMI- (semistratified-) the beginning of destratification (from September to end of October). During the SEMI-period, water column temperature was significantly higher than during the SEMI+ period. The stratified period merged into the second $M I X+$ period (from November to end of December) as described above. Negative $\Delta t$, mixed water mass, is called here $M I X$ - (from January to mid March 1994 ) with about $13^{\circ} \mathrm{C}$ at surface and a slight increase at deeper waters. This period gave way to the $M I X+$ period at the end of our annual observation. Temperature variations in these 5 periods are summarised in Fig. 1A. Fig. 1B shows the vertical temperature profiles of these 5 periods with data obtained in 1993.

Classification of DYP particles: To investigate natural groupings among the different detrital size classes, the data set ( 5 size classes of DYP in water column with 52 dates) was standardized. Hierarchical flexible clustering, with $\beta=-0.25$ on a matrix of Euclidean distances among the standardized data was performed according to Legendre \& Legendre (1984).

Correlation analyses: A correlation matrix was employed with 6 variables $(\leq 10 \mu \mathrm{m}$ DYP, $10-20 \mu \mathrm{m}$ DYP, chl $a$, bacteria, heterotrophic flagellates and oligotrich ciliates) using integrated water column values for each hydrographic condition and for the whole study period.

\section{RESULTS}

\section{Classification of DYP}

Results of DYP classification are revealed that 2 major groups can be separated corresponding roughly to particles $\leq 10 \mu \mathrm{m}$ and $>10 \mu \mathrm{m}$. The $\leq 10 \mu \mathrm{m}$ group can be further divided into subgroups by depths with particles at 0 and $20 \mathrm{~m}$ separated from 40 and $75 \mathrm{~m}$ (details not shown).

\section{DYP number and surface area}

The number of detrital particles ( \pm SE) decreased remarkably with increase in size from $17 \pm 2 \times 10^{3} \mathrm{ml}^{-1}$ to $9 \pm 4 \mathrm{ml}^{-1}$ for $0.2-2 \mu \mathrm{m}$ DYP and 15-20 $\mu \mathrm{m}$ DYP, respectively. Fig. $2 \mathrm{~A}$ illustrates abundance variations of DYP at the 4 depths sampled. Generally, particle concentrations did not differ with depth from 0 to $75 \mathrm{~m}$ (Fig. 2). Total surface area of 2-5 $\mu$ m DYP was much larger than other size fraction of DYP at all depths. The surface area $( \pm \mathrm{SE}$ ) of DYP $2-5 \mu \mathrm{m}$ ranged from $76 \pm 11$ $\mathrm{mm}^{2} \mathrm{l}^{-1}$ in surface waters decreasing to $45 \pm 4 \mathrm{~mm}^{2} \mathrm{l}^{-1}$ at $75 \mathrm{~m}$ (Fig. 2B).

\section{General trends in DYP concentrations}

Reflecting the classification analysis, particles $\leq 10 \mu \mathrm{m}$ co-varied, all showing marked minima during the stratified season and peak concentrations often occurring during periods of transition from one hydrographic period to the next (Fig. 3). Among particles 10-20 $\mu \mathrm{m}$ in size, the larger size class $(15-20 \mu \mathrm{m})$ occurred sporadically, obscuring general trends. The smaller size class $(10-15 \mu \mathrm{m})$ appeared to be distinct from other size classes as it often showed subsurface peaks in concentration (Table 1).

\section{General trends in concentrations of micro-organisms}

Among microbial populations, bacteria showed the least variability with depth and a lack of clear seasonal trends (Fig. 4). Ciliates and heterotrophic microflagellates both generally decreased in abundance with depth and displayed pronounced periods of maximum concentration in early spring.
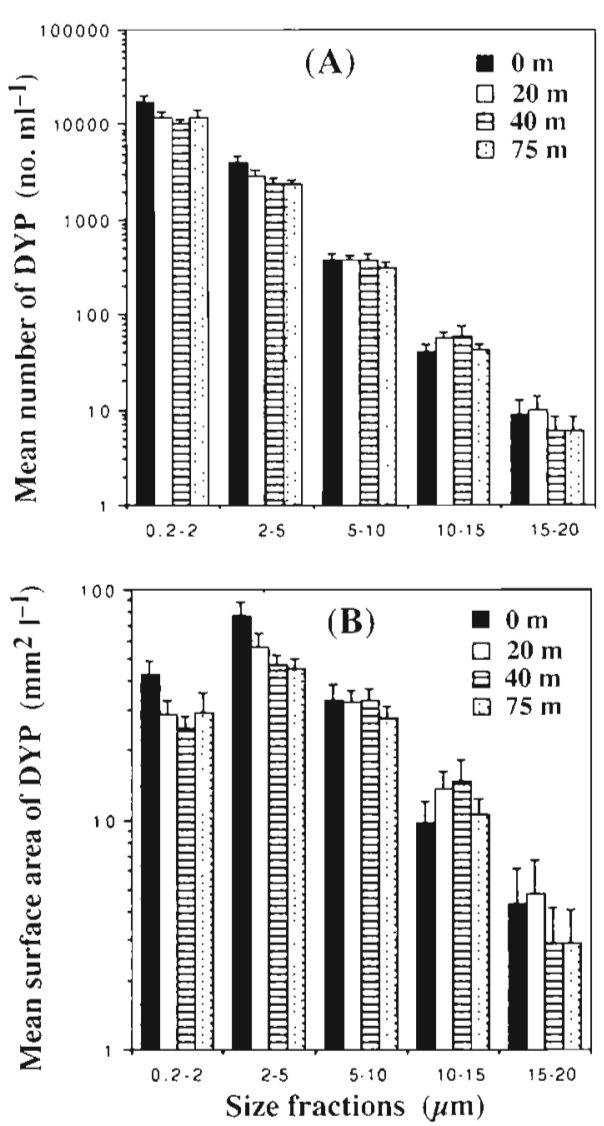

Fig. 2. Number and surface areas of different size classes of DYP. (A) Logarithmic plot of annual mean number of DYP; (B) logarithmic plot of annual mean surface of DYP. Bars represent standard errors 

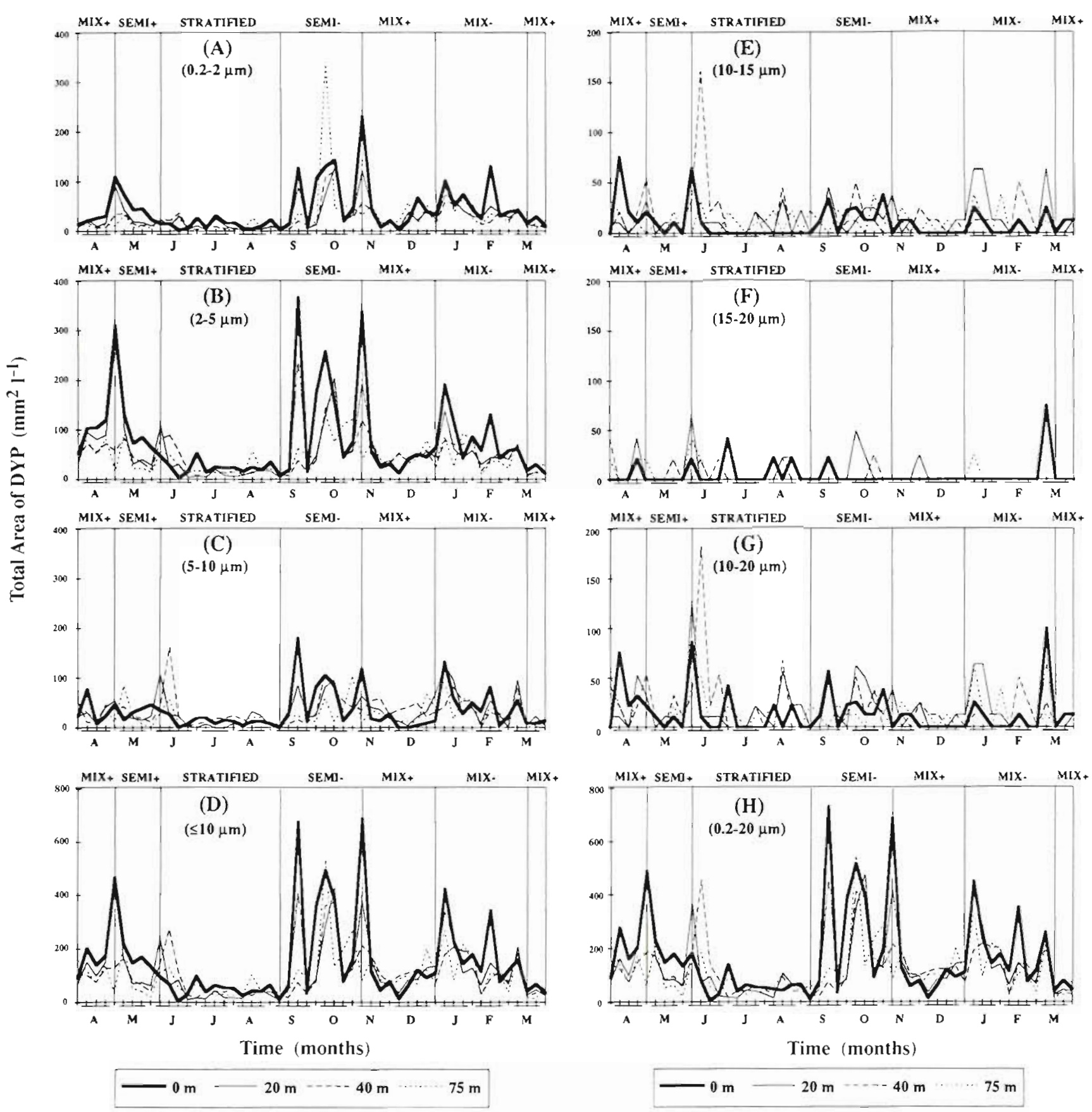

Fig. 3. Weekly variations of pico- and nano-detrital particles from March 31, 1993, to March 30, 1994, in the Ligurian Sea, NW Mediterranean. Particle size ( $\mathrm{rm}$ ): (A) 0.2-2, (B) 2-5. (C) 5-10, (D) $\leq 10$, (E) 10-15, (F) 15-20, (G) 10-20, (H) $0.2-20$

\section{Relationships between DYP, chl a and heterotrophic microbial organisms}

Correlation analysis (Table 2) of integrated water column values over the whole study period did not indicate any strong relationships between either of the major DYP groups and chl a or microbes. Concentrations of $\leq 10 \mu \mathrm{m}$ and $>10 \mu \mathrm{m}$ particles were significantly related to each other as were chl a and heterotrophic microflagellates as well as ciliates and heterotrophic microflagellates. The correlations found overall were the result of strong relationships between $\leq 10 \mu \mathrm{m}$ and $>10 \mu \mathrm{m}$ particles during the stratified period and the

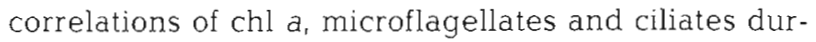
ing mixed water column periods. Among the different hydrographic periods, the transitional periods between 


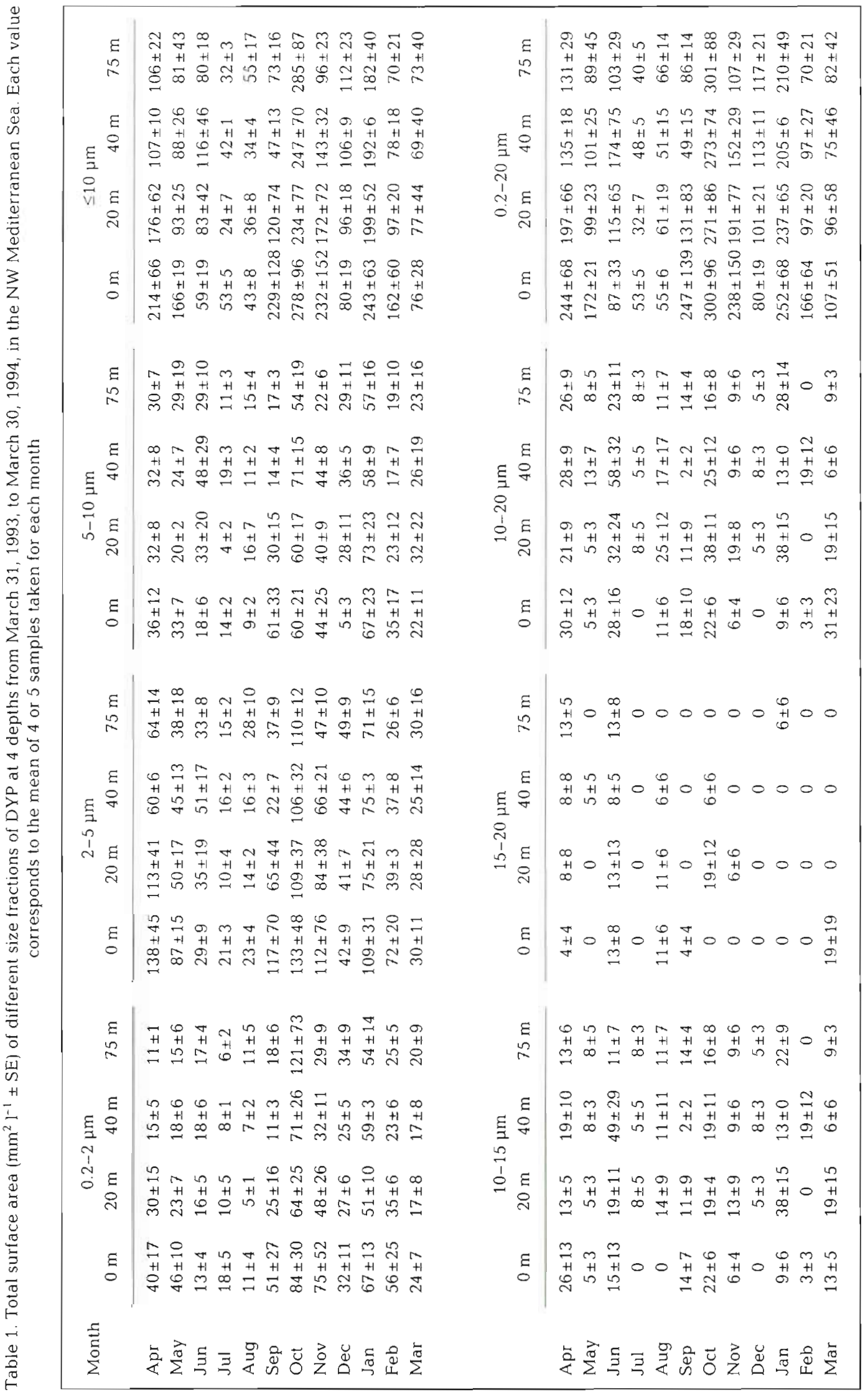




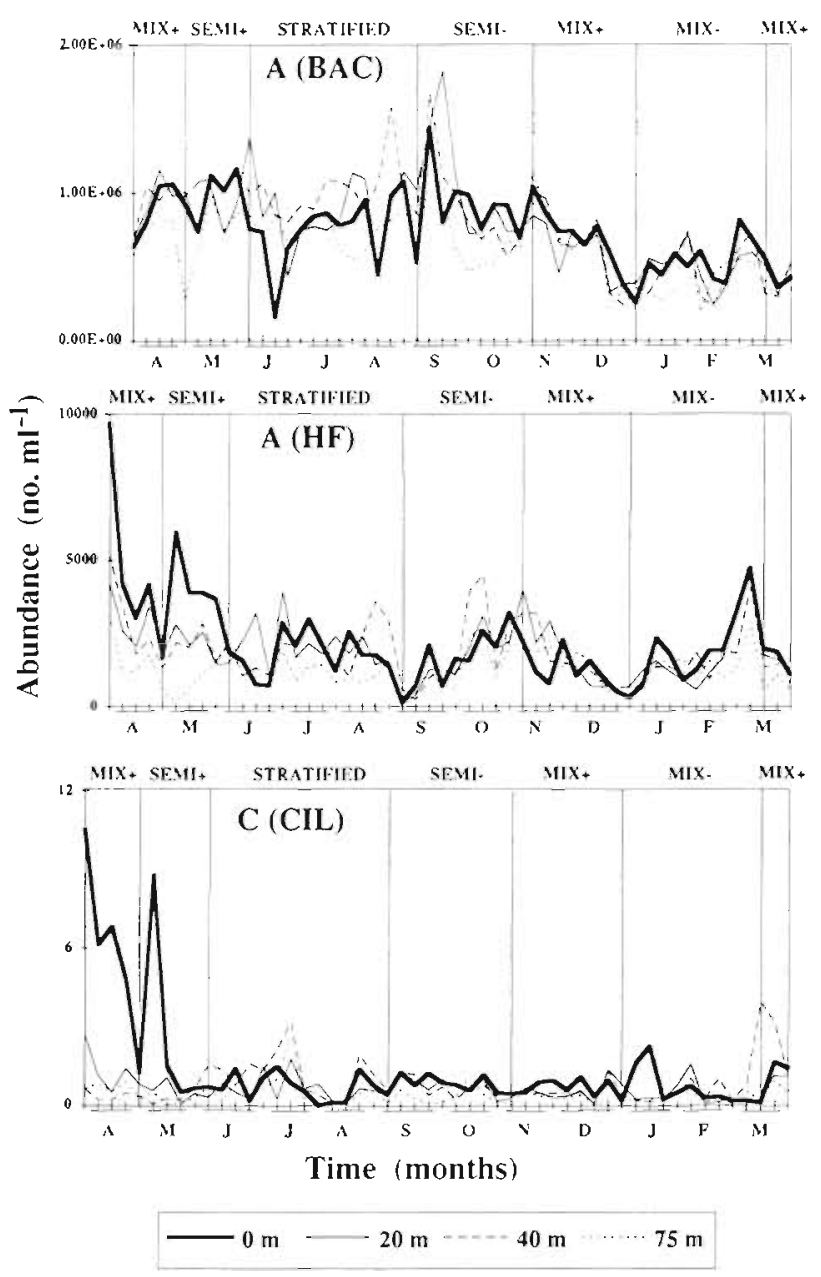

Fig. 4. Seasonal variations of (A) bacteria, (B) heterotrophic flagellates. (C) oligotrich ciliates in different hydrological conditions from March 31, 1993, to March 30, 1994, in the Ligurian Sea

stratified and mixed conditions (SEMI+, SEMI-) showed no strong significant relationship between any of the parameters. However, during the SEMI-period a significant relationship between $\leq 10 \mu \mathrm{m}$ DYP and heterotrophic flagellates was detected as well as a relationship between $\leq 10 \mu \mathrm{m}$ DYP and ciliates during the SEMI+ period. Noteworthy was the apparent independence of bacterial concentrations except for a weak correlation with $\leq 10 \mu \mathrm{m}$ DYP during the $M I X+$ period of late autumn/early winter

Analysis of temporal trends of chl a and concentrations of the 2 major groups of DYP (Fig. 5) showed qualitative similarities. DYP concentrations showed 'pulses' similar to those of chl a; marked declines in chl a concentrations were followed by increases in DYP in samples taken the following week. The relationship was qualitative; amplitudes of chl a oscillations were not quantitatively related to the amplitudes of DYP oscillations.

\section{DISCUSSION}

\section{DYP compared to other particulate organic matter}

DYP in the present investigation overlap the lower size range of detritus $(\leq 20 \mu \mathrm{m})$ studied by Riley (1963). Riley et al. (1964, 1965), Kane (1967) and Gordon (1970) as well as the 'Transparent Exopolymer Particles' (TEP) reported by Passow \& Alldredge (1994) Table 3 summarises data from earlier and recent studies of particulate matter, as well as for the DYP presented here. Number and total surface area of $\leq 10 \mu \mathrm{m}$ DYP reported here are much higher than previously found for 'micro' organic aggregates in the NW Mediterranean (Kane 1967) and other systems as well (Riley 1963, Riley et al. 1964, 1965, Gordon 1970). Compared to data from more recent studies on marine snow, nano- and pico-DYP are considerably more abundant than 'macro'-sized aggregates, commonly

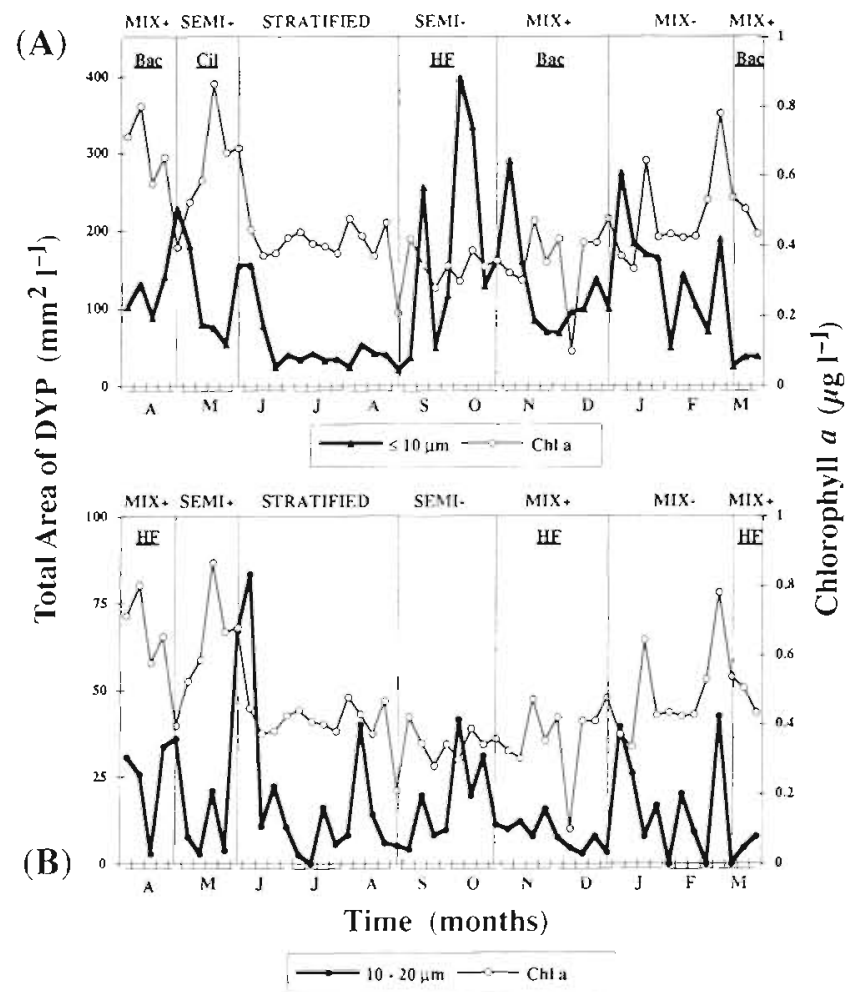

Fig. 5. Temporal changes of DYP and chl a during 5 hydrographic periods in Villefranche Bay from March 31, 1993, to March 30, 1994, based on weekly sampling. The values are integrated over the water column from surface waters to $75 \mathrm{~m}$. (A) DYP $\leq 10 \mu \mathrm{m}$ and $\mathrm{chl}$ a. Significant correlations between DYP $\leq 10 \mu \mathrm{m}$ and bacteria (Bac) in MIX+ periods, ciliates (Cil) in SEMI+ period and heterotrophic flagellates (HF) in SEMIperiod are underlined. (B) 10-20 $\mu \mathrm{m}$ DYP and chl a. Large DYP were significantly correlated with heterotrophic flagellates in $M I X+$ periods (see text) 
Table 2. Correlation matrix for 6 variables integrated throughout the water column from 0 to $75 \mathrm{~m}$ : chlorophyll a (chl), 2 size classes of DYP ( $\leq 10$ and 10-20 $\mu \mathrm{m}$ ), bacteria (Bac), heterotrophic flagellates (HF) and oligotrich ciliates (Cil) throughout the entire study period and within different hydrographic periods. Underlined values with " and " ${ }^{*}$ are significant at $p=0.05$ and $p=0.01$ levels, respectively

\begin{tabular}{|c|c|c|c|c|c|c|c|c|c|c|c|c|c|}
\hline & \multicolumn{6}{|c|}{ WHOLE PERIOD $(\mathrm{n}=52)$} & \multicolumn{7}{|c|}{ STRATIFIED $(\mathrm{n}=13)$} \\
\hline & Chl & $\leq 10$ & $10-20$ & $\mathrm{Bac}$ & $\mathrm{HF}$ & Cil & & Chl & $\leq 10$ & $10-20$ & $\mathrm{Bac}$ & $\mathrm{HF}$ & Cil \\
\hline Chl & 1 & & & & & & Chl & 1 & & & & & \\
\hline$\leq 10$ & -0.083 & 1 & & & & & $\leq 10$ & 0.248 & 1 & & & & \\
\hline $10-20$ & 0.19 & $\underline{0.454} \cdots$ & 1 & & & & $10-20$ & 0.228 & $\underline{0.854}{ }^{\cdots}$ & 1 & & & \\
\hline $\mathrm{Bac}$ & 0.062 & -0.05 & 0.086 & 1 & & & $\mathrm{Bac}$ & 0.17 & 0.029 & -0.166 & 1 & & \\
\hline $\mathrm{HF}$ & $0.458 \cdots$ & $0.297^{\circ}$ & 0.258 & 0.194 & 1 & & $\mathrm{HF}$ & $\underline{0.591^{\circ}}$ & 0.09 & -0.068 & 0.46 & 1 & \\
\hline \multirow[t]{3}{*}{ Cil } & $0.309^{\circ}$ & -0.143 & -0.009 & 0.097 & $\underline{0.391^{*}}$ & 1 & $\mathrm{Cil}$ & 0.077 & 0.051 & -0.215 & 0.269 & 0.483 & 1 \\
\hline & \multicolumn{6}{|c|}{$S E M I+(\mathrm{n}=5)$} & \multicolumn{7}{|c|}{$S E M I-(\mathrm{n}=8)$} \\
\hline & Chl & $\leq 10$ & $10-20$ & Bac & $\mathrm{HF}$ & Cil & & Chl & $\leq 10$ & $10-20$ & $\mathrm{Bac}$ & $\mathrm{HF}$ & Cil \\
\hline Chl & 1 & & & & & & Chl & 1 & & & & & \\
\hline$\leq 10$ & -0.484 & 1 & & & & & $\leq 10$ & -0.144 & 1 & & & & \\
\hline $10-20$ & 0.281 & 0.433 & 1 & & & & $10-20$ & -0.381 & $0.751^{\circ}$ & 1 & & & \\
\hline $\mathrm{Bac}$ & -0.097 & -0.418 & 0.201 & 1 & & & Bac & 0.457 & -0.376 & -0.489 & 1 & & \\
\hline $\mathrm{HF}$ & 0.323 & 0.319 & -0.053 & $-0.896^{\circ}$ & 1 & & $\mathrm{HF}$ & -0.056 & $\underline{0.803^{\circ}}$ & 0.513 & -0.641 & 1 & \\
\hline \multirow[t]{3}{*}{ Cil } & -0.791 & $\underline{0.892^{\circ}}$ & 0.087 & -0.34 & 0.097 & 1 & Ci] & 0.676 & -0.133 & -0.165 & 0.645 & -0.343 & 1 \\
\hline & \multicolumn{6}{|c|}{$M I X+(n=16)$} & \multicolumn{7}{|c|}{$M I X-(n=10)$} \\
\hline & Chl & $\leq 10$ & $10-20$ & $\mathrm{Bac}$ & $\mathrm{HF}$ & Cil & & Chl & $\leq 10$ & $10-20$ & $\mathrm{Bac}$ & $\mathrm{HF}$ & Cil \\
\hline Chl & 1 & & & & & & Chl & 1 & & & & & \\
\hline$\leq 10$ & -0.134 & 1 & & & & & $\leq 10$ & -0.072 & 1 & & & & \\
\hline $10-20$ & 0.478 & 0.386 & 1 & & & & $10-20$ & 0.079 & $\underline{0.874^{\circ}}$ & 1 & & & \\
\hline $\mathrm{Bac}$ & 0.107 & $\underline{0.515^{\circ}}$ & 0.461 & 1 & & & $\mathrm{Bac}$ & 0.472 & 0.166 & 0.148 & 1 & & \\
\hline $\mathrm{HF}$ & $\underline{0.502^{\circ}}$ & 0.247 & $\underline{0.574^{\circ}}$ & $0.553^{\circ}$ & 1 & & $\mathrm{HF}$ & $\underline{0.773^{\circ}}$ & 0.053 & 0.364 & 0.514 & 1 & \\
\hline Cil & $0.701^{\circ}$ & -0.233 & 0.43 & 0.06 & $\underline{0.631^{\cdots}}$ & 1 & Cil & 0.252 & -0.537 & -0.278 & -0.114 & 0.086 & 1 \\
\hline
\end{tabular}

reported in concentrations of 1 to $10 \mathrm{l}^{-1}$ (Alldredge \& Silver 1988) and rarely more abundant than 291 to 489 $\mathrm{l}^{-1}$ (Wells \& Shanks 1987). The size range of DYP overlaps the lower size range of TEP (Passow \& Alldredge 1994), although the abundance of DYP in the Mediterranean Sea is higher than TEP reported from other systems. However, compared to smaller 'particles', colloid aggregates $>1 \mu \mathrm{m}$ have been reported with a concentration of $10^{5}$ colloid aggregates $\mathrm{ml}^{-1}$ (Wells \& Goldberg 1993), which is about the same order of magnitude as DYP $\leq 10 \mu \mathrm{m}$ in the present study. It should be noted that smaller colloids are much more abundant than colloid aggregates (Table 3 ).

In terms of particle surface area, DYP $\leq 10 \mu \mathrm{m}$ appear to be more abundant than, or about equal to, larger organic aggregates based on previous reports. For example, total area of DYP $\leq 10 \mu \mathrm{m}$ given here compared to surface areas of organic aggregates reported by Riley (1963) for Long Island Sound are of the same order of magnitude (Table 3). The surface area of all other organic aggregates from other sites (reported by Riley et al. 1965, Kane 1967 and Gordon 1970) are about an order of magnitude less than those of DYP $\leq 10 \mu \mathrm{m}$ reported here (Table 3 ).

Total area of DYP $\leq 10 \mu \mathrm{m}$ and that of TEP reported by Passow \& Alldredge (1994) from 3 different systems are also of the same order of magnitude $\left(43\right.$ to $278 \mathrm{~mm}^{2}$ $\mathrm{I}^{-1}$ of DYP compared with 0.2 to $650 \mathrm{~mm}^{2} \mathrm{l}^{-1}$ of TEP). However, the authors emphasized that total area of TEP can vary by 4 orders of magnitude $(0.2$ to 2000 $\mathrm{mm}^{2} \mathrm{l}^{-1}$ ) and high concentrations of TEP were associated with flocculating diatom blooms (Alldredge et al. 1993).

\section{DYP in the Ligurian Sea}

The present investigation suggests a classification of DYP into 2 groups with possible different origins. Hierarchical clustering classification separated the small $\leq 10 \mu \mathrm{m}$ DYP from the larger ones. Peaks of $\leq 10 \mu \mathrm{m}$ DYP (Fig. 5A) were observed during hydrographic shift periods (e.g. between $M I X+$ and SEMI+, SEMI+ and STRATIFIED). In these periods, chl a decreased 
Table 3. Comparison of the numbers and total surface areas of DYP $\leq 10 \mu \mathrm{m}$ with reports of particulate matter from early and recent studies

\begin{tabular}{|c|c|c|c|c|c|c|}
\hline \multirow{2}{*}{$\begin{array}{l}\text { Particles } \\
\text { (size range) }\end{array}$} & \multicolumn{2}{|c|}{ Number $\left(\times 10^{3} 1^{-1}\right\}$} & \multicolumn{2}{|c|}{ Total area $\left(\mathrm{mm}^{2} \mathrm{l}^{-1}\right)$} & \multirow[t]{2}{*}{ Study site } & \multirow[t]{2}{*}{ Source } \\
\hline & Range & Mean & Range & Mean & & \\
\hline $\begin{array}{l}\text { Organic aggregates } \\
\text { ( } 5 \mu \mathrm{m} \text { to several } \mathrm{mm} \text { ) }\end{array}$ & $30-100$ & - & $23-167$ & - & $\begin{array}{l}\text { Long Island Sound, USA } \\
\text { (coastal) }\end{array}$ & Riley (1963) \\
\hline $\begin{array}{l}\text { Organic aggregates } \\
\text { ( } 5 \mu \mathrm{m} \text { to several } \mathrm{mm} \text { ) }\end{array}$ & $8-40$ & 11.32 & $3-9.9$ & - & $\begin{array}{l}\text { N Equatorial Current } \\
\text { (open sea) }\end{array}$ & Riley et al. (1965) \\
\hline $\begin{array}{l}\text { Organic aggregates } \\
(5 \mu \mathrm{m} \text { to several } \mathrm{mm})\end{array}$ & - & - & $3-38$ & - & $\begin{array}{l}\text { Guinea Current } \\
\text { (open sea) }\end{array}$ & Riley et al. (1965) \\
\hline $\begin{array}{l}\text { Organic aggregates } \\
\text { (5 } \mu \mathrm{m} \text { to several } \mathrm{mm})\end{array}$ & $30-100$ & - & - & - & $\begin{array}{l}\text { Off west coast of Africa } \\
\text { (coastal) }\end{array}$ & Riley et al. (1965) \\
\hline $\begin{array}{l}\text { Organic aggregates } \\
(10-260 \mu \mathrm{m})\end{array}$ & $1.9-64$ & 12.5 & $1-52$ & 11.5 & $\begin{array}{l}\text { Ligurian Sea, off Monaco } \\
\text { (coastal) }\end{array}$ & Kane (1967) \\
\hline $\begin{array}{l}\text { Organic aggregates } \\
(10-260 \mu \mathrm{m})\end{array}$ & $1.9-15$ & 6.3 & $1-10$ & 4.6 & $\begin{array}{l}\text { Ligurian Sea, off Monaco } \\
\text { (open sea) }\end{array}$ & Kane (1967) \\
\hline $\begin{array}{l}\text { Organic aggregates } \\
(<5 \mu \mathrm{m})\end{array}$ & $32-235$ & - & - & - & $\begin{array}{l}\text { N Atlantic Ocean, from } \\
\text { Sargasso Sea to Irminger Sea }\end{array}$ & Gordon $(1970)$ \\
\hline $\begin{array}{l}\text { Marine snow } \\
(>500 \mu \mathrm{m})\end{array}$ & $0-8 \times 10^{-3}$ & - & - & - & Santa Barbara, CA, USA & $\begin{array}{l}\text { Alldredge (1979). For } \\
\text { more details see All- } \\
\text { dredge \& Silver (1988) }\end{array}$ \\
\hline $\begin{array}{l}\text { Marine snow } \\
(4 \pm 5 \mathrm{~mm})\end{array}$ & - & $7.0 \pm 1.2 \times 10^{-3}$ & - & - & NE Atlantic Ocean & Shanks \& Trent (1980) \\
\hline $\begin{array}{l}\text { TEP } \\
\text { ( } 3 \text { to several } 100 \mu \mathrm{m})\end{array}$ & $10^{0}-10^{4}$ & - & $0.2-2000$ & - & $\begin{array}{l}\text { Monterey Bay-Santa } \\
\text { Barbara-Bermuda }\end{array}$ & $\begin{array}{l}\text { Passow \& Alldredge } \\
\text { (1994) }\end{array}$ \\
\hline $\begin{array}{l}\text { DYP } \\
(0.2-10 \mu \mathrm{m})\end{array}$ & $744-112516$ & $21619 \pm 3237$ & $43-278$ & $153 \pm 55$ & $\begin{array}{l}\text { Ligurian sea off Villefranche } \\
\text { (coastal) surtace waters }\end{array}$ & This study \\
\hline $\begin{array}{l}\text { Sub-micron particles } \\
(0.38-1 \mu \mathrm{m})\end{array}$ & $5-8 \times 10^{7}$ & - & - & - & $\begin{array}{l}\text { N Pacific Ocean } \\
\text { (top } 40 \mathrm{~m} \text { ) }\end{array}$ & Koike et al. (1990) \\
\hline $\begin{array}{l}\text { Sub-micron particles } \\
(0.36-1.01 \mu \mathrm{m})\end{array}$ & - & $1.43-2.35 \times 10^{7}$ & - & - & $\begin{array}{l}\text { NW Atlantic shelf water } \\
\text { (offshore; } 10 \mathrm{~m} \text { ) }\end{array}$ & Longhurst et al. (1992) \\
\hline $\begin{array}{l}\text { Colloid aggregates } \\
(>1.0 \mu \mathrm{m})\end{array}$ & - & $10^{5}$ & - & - & $\begin{array}{l}\text { Atlantic and Pacific Oceans } \\
\text { (mid-depth and deep waters) }\end{array}$ & $\begin{array}{l}\text { Wells \& Goldberg } \\
\text { (1993) }\end{array}$ \\
\hline $\begin{array}{l}\text { Colloids } \\
(0.005-0.2 \mu \mathrm{m})\end{array}$ & - & $10^{9}$ & - & - & $\begin{array}{l}\text { N Atlantic and Southern } \\
\text { Oceans }\end{array}$ & $\begin{array}{l}\text { Wells \& Goldberg } \\
\text { (1994) }\end{array}$ \\
\hline
\end{tabular}

sharply, presumably due to sedimentation of phytoplanktonic cells or intensive grazing by heterotrophic organisms. In either case the occurrence of large quantities of detrital particles (mortality of phytoplanktonic cells, faecal production and carcasses of organisms) is not surprising. In contrast to isolated peaks before stratification, at the end of long stratification in the SEMI-period, 2 large peaks of $\leq 10 \mu \mathrm{m}$ DYP were also observed in September and October (the second one was the highest for the studied year). In this period, chl a was lowest $\left(0.34 \pm 0.01 \mu \mathrm{g} \mathrm{l}^{-1}\right)$ and did not show any sharp shifts. Therefore, in this period the high amount of $\leq 10 \mu \mathrm{m}$ DYP cannot be explained by a drop in chl a. Thus, there was probably another source of $\leq 10 \mu \mathrm{m}$ DYP in the SEMI-period. Abundance trends of DYP $>10 \mu \mathrm{m}$ appeared to track chl a more closely than smaller particles (Fig. 5B) but over the entire study period there was no significant correlation.

Sources of DYP and its trophic importance may vary seasonally. For example, large DYP $(10-20 \mu \mathrm{m})$ were correlated only with heterotrophic flagellates in the $M I X+$ period and no other correlation of these large DYP was observed at any time with microbes (see Table 2). 
The $\leq 10 \mu \mathrm{m}$ DYP correlation with bacteria, heterotrophic flagellates and ciliates is even more interesting. During the MIX+ period, bacteria were significantly correlated with this small DYP. During the SEMI- period, heterotrophic flagellates were significantly correlated with $\leq 10 \mu \mathrm{m}$ DYP and not with any other parameters investigated here (Table 2). This significant correlation occurred during the SEMI+ period between ciliates and $\leq 10 \mu \mathrm{m}$ DYP. This suggests a variable linkage of DYP with the microbial food web during certain periods.

\section{Speculations on the origins and fates of DYP}

The idea that particulate organic matter (POM) may be formed via coagulation by bubbling of dissolved organic carbon (DOC) has been discussed for over 30 yr. Riley (1963), Sutcliffe et al. (1963), Riley et al. (1964), Barber (1966), Batoosingh et al. (1969), Corner et al. (1974), Biddanda (1985), and Kepkay \& Johnson $(1988,1989)$ all provided some evidence on the conversion of dissolved organic matter (DOM) to POM by bubbling. More recently, Wells \& Goldberg (1994) proposed a likely primary source of marine colloids as the agglomeration of some fraction of the truly dissolved organic phase.

In the NW Mediterranean, at least, DOC concentrations appear dynamic. Copin-Montégut \& Avril (1993) detailed monthly vertical profiles of DOC 28 miles offshore of Villefranche. These authors concluded that DOC accumulated in surface waters throughout the stratified period and was then dispersed through water column mixing. Thus, considering wind forcing at the end of the stratified period on water mass mixing, it may be hypothesized that adsorption on bubbles could produce directly or indirectly the DYP that we observed during destratification (e.g. DOC adsorption on bubbles and production of colloids, and then agglomeration of colloids giving DYP).

In the SEMI-period, surface waters cooled due to wind stress, and consequently water column mixing began. In this period, the high observed value of $\leq 10 \mu \mathrm{m}$ DYP might be explained by physical mechanisms (conversion of DOC to DYP). Two peaks of $\leq 10 \mu \mathrm{m}$ DYP in the SEMI-period were followed by a 10-20 $\mu \mathrm{m}$ DYP peak. The sharp decrease of $\leq 10 \mu \mathrm{m}$ DYP at the end of this period coincided with a third peak of DYP $10-20 \mu \mathrm{m}$. These fluctuations could be explained by a scenario in which $\leq 10 \mu \mathrm{m}$ DYP formation (in the way of coagulation of DOC on bubble surfaces) was followed by the formation of large DYP. Two high peaks of $\leq 10 \mu \mathrm{m}$ DYP were followed by another one in the $M I X+$ condition. During this period, chl a decreased. Disaggregation of $10-20 \mu \mathrm{m}$ DYP formed at the end of SEMI-period could explain this peak of $\leq 10 \mu \mathrm{m}$ DYP. This case fits in the detritus cycle scheme suggested by Biddanda \& Pomeroy (1988) with distinct phases of aggregation, disaggregation, re-aggregation and finally sinking out of the water column.

In the MIX-period the peaks of DYP seem to be regular especially for 10-20 $\mu \mathrm{m}$ detrital particles. In other words, during the MIX-period, DYP variations correspond with the scheme proposed by Biddanda \& Pomeroy (1988). Nevertheless, in contrast with the fate of detritus in Biddanda \& Pomeroy's scheme, DYP do not seem to sink to the deep layer, at least in the NW Mediterranean. Miquel et al. (1994), employing sediment trap data, presented the dynamics of the downward flux of particles and carbon in the open NW Mediterranean Sea. These authors did not observe a high value of downward particulate mass flux at the end of the stratified condition where $\leq 10 \mu \mathrm{m}$ DYP peaked sharply.

Another possible source of DYP could be protozoan egesta. This idea corresponds with the hypothesis of Nagata \& Kirchman (1992) that flagellates release their own digestive enzymes and incompletely digested membranes and probably other cellular components from bacterial prey. Indeed, several authors have reported on small particle production by protozoa (Stoecker 1984, Nöthig \& von Bodungen 1989, Buck et al. 1990, Elbrächter 1991, González 1992, Buck \& Newton 1995).

Concerning possible settling rates of DYP, little comparative data is available. Some values of settling rates of organic aggregates have been given in the literature: 1 to $7 \mathrm{~m} \mathrm{~d}^{-1}$ (Riley et al. 1965), 0.14 to $12 \mathrm{~m} \mathrm{~d}^{-1}$ (Hobson 1967), 0.10 to $0.57 \mathrm{~m} \mathrm{~d}^{-1}$ for particles of 2 to $6 \mu \mathrm{m}$ (Riley 1970). Such settling rates are much lower than those found for diatoms, 100 to $150 \mathrm{~m} \mathrm{~d}^{-1}$ (Billet et al. 1983), zooplankton faeces, 29 to $122 \mathrm{~m} \mathrm{~d}^{-1}$ (Lorenzen \& Welschmeyer 1983, Fowler et al. 1987) and marine snow aggregates, 50 to $100 \mathrm{~m} \mathrm{~d}^{-1}$ (Shanks \& Trent 1980, Alldredge \& Gotschalk 1990). This suggests that small particles are probably distributed solely by advection; settling becomes more important with progressively larger particles (Gordon 1970).

Trophic interactions between detritus and microorganisms were investigated by several authors. Riley (1963) was among the first to suggest that organic aggregates provide a substrate for bacterial growth and probably food for zooplankton. Several authors reported a rapid bacterial colonization of detritus followed by the development of protozoa. Detrital particles, colonized by bacteria, can come from different sources including phytoplankton (Hoppe 1981, Linley \& Newell 1984, Fukami et al. 1985), zooplankton (Fukami et al. 1985), faecal pellets (Pomeroy \& Diebel 1980, Jacobsen \& Azam 1984) and organic particle 


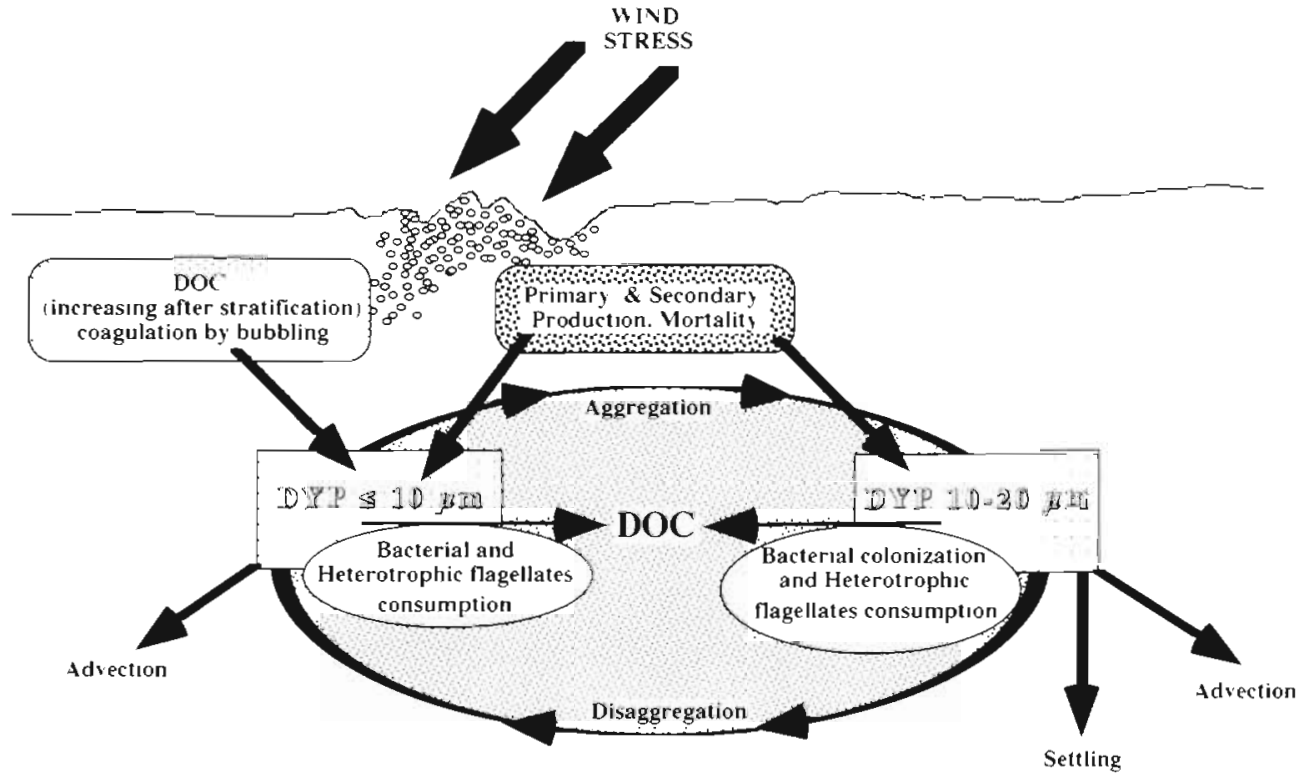

Fig. 6. Speculative schematic model of the 'detrital loop' indicating origins, trophic importance, fate and interactions of DYP in the microbial food web through the water column. See 'Discussion' for details generation by surface coagulation (Kepkay \& Johnson 1988, 1989) We think that DYP, with their seemingly negligible settling rate and their large surface/volume ratio, could be a significant resource in supplying nutrients for the regenerated production in planktonic systems. The relatively large amounts of DYP in the water column indicate a potentially important role for these particles as one of the sources for remineralization processes within the microbial food web.

Fig. 6 shows a speculative schematic model of a 'detrital loop' and summarises our discussion about orlgins, trophic importance, fate and interactions of DYP in the microbial food web through the water column. As this scheme illustrates, there are at least 2 possible origins of DYP formation. One is the primary and secondary production as suggested by Biddanda \& Pomeroy (1988) Indeed, the mortality of organisms could add to this source The second is DOC which can be converted to DYP $\leq 10 \mu \mathrm{m}$ via coagulation by bubbling This phenomenon could be impartant after a stratification period in which DOC increased in surface water followed by a penod of wind-driven mixing There appear to be qualitative differences between DYP $\leq 10 \mu \mathrm{m}$ and larger DYP as smaller DYP are much less intensıvely colonızed by bacterıa (Mostajır et al. 1995). Aggregation of DYP $\leq 10 \mu \mathrm{m}$ to DYP 10-20 $\mu \mathrm{m}$ could be either a purely physical phenomenon or a biological process or both. Some DYP $\leq 10 \mu \mathrm{m}$ could leave the system by advection The ongin of DYP $10-20 \mu \mathrm{m}$ is possibly the result of DYP $\leq 10 \mu \mathrm{m}$ aggregation, or direct production by primary or secondary producers. The fate of DYP $10-20 \mu \mathrm{m}$ is potentially disaggregatıon, producing DYP $\leq 10 \mu \mathrm{m}$, or exiting from the system via settling or advection
Acknowledgements We thank R. Charra for chlorophyll measurement, D. Bettl and R. Charra for their regular sampling in Villefranche Bay, M Perez Mediavilla for her help in counting of some clliate slides. J. M. Fromentin and B. Planque for their help in statıstıcal treatments, and P. Verity, M. Karner and B. Avrl as well as 3 anonymous reviewers for their constructive comments on the manuscript. The work presented here is part of the doctoral dissertation of B.M. Financial support was provided by the CNRS/INSU (URA 716) and E.E.C. MAST IIMTP (Mediterranean Targeted Program, contract MAST IICT93-0063, Medipelagos\}.

\section{LITERATURE CITED}

Alldredge AL (1979) The chemical composition of macroscopic aggregates in two neritic seas. Limnol Oceanogr 24 : $855-866$

Alldredge AL, Gotschalk CC (1990) The relative contribution of marne snow of different origins to biological processes in coastal waters Cont Shelf Res 10:41-58

Alldredge AL, Passow U, Logan BE (1993) The abundance and significance of a class of large, transparent organic particles in the ocean. Deep Sea Res 40:1131-1140

Alldredge AL. Silver MW (1988) Characteristics, dynamics and significance of marine snow. Prog Oceanogr 20:41-82

Barber RT (1966) Interaction of bubbles and bacteria in the formation of organic aggregates in sea-water. Nature 211 $257-258$

Batoosingh E, Rıley GA, Keshwar B (1969) An analysis of expermental methods for producing particulate organic matter in sea water by bubbling. Deep Sea Res 16: 213-219

Biddanda BA (1985) Microbial synthesis of macroparticulate matter Mar Ecol Prog Ser 20:241-251

Biddanda BA. Pomeroy LR (1988) Microbial aggregation and degradation of phytoplankton-derived detritus in seawater I Microblal succession. Mar Ecol Prog Ser 42:79-88

Billett DSM, Lampitt RS, Rice AL (1983) Seasonal sedimentation of phytoplankton to the deep-sea benthos. Nature $302520-522$ 
Buck KR, Bolt PA, Garrison DL (1990) Phagotrophy and fecal pellet production by an athecate dinoflagellate in Antarctic Sea ice. Mar Ecol Prog Ser 60:75-84

Buck KR, Newton J (1995) Fecal pellet flux in Dabob Bay during a diatom bloom: contribution of microzooplankton. Limnol Oceanogr 40(2):306-315

Bustıllos-Guzmán J, Claustre H, Marty JC (1995) Specific phytoplankton signatures and their relationship with hydrographic conditions in the coastal Northwestern Mediterranean Sea. Mar Ecol Prog Ser 124:247-258

Copin-Montégut G, Avrnl B (1993) Vertical distribution and temporal varlation of dissolved organic carbon in the North-Western Mediterranean Sea. Deep Sea Res 40: 1963-1972

Corner EDS, Head RN, Kilvington CC (1974) On the nutrition and metabolism of zooplankton IX. Studies relating to the nutrition of overwintering Calanus. I mar Biol Ass UK 54: 319-331

Elbrächter M (1991) Faeces production by dinoflagellates and other small flagellates. Mar microb Food Webs 5(2): 189-204

Etienne M, Corre MC, Dallot S, Nival P (1991) Observations hydrologiques à une station côtière méditerranéenne. Point B - rade de Villefranche-sur-mer $\left(43^{\circ} 41^{\prime} 10^{\prime \prime} \mathrm{N}\right.$ $7^{\circ} 19^{\prime} 00^{\prime \prime} \mathrm{E}$ ). IFREMER, Campagnes Océanographiques Françaises 14:1-89

Fowler SW, Buat-Ménard P, Yokoyama S, Ballestra S, Holm E, Nguyen HV (1987) Rapid removal of Chernobyl fallout from the Mediterranean surface waters by biological activity. Nature 329:56-58

Fowler SW, Knauer GA (1986) Role of large particles in the transport of elements and organic compounds through the oceanic water column. Prog Oceanogr 16:147-194

Fukami K, Simuda U, Taga N (1985) Microbıal decomposition of phyto-and zooplankton in seawater. Il. Changes in the bactenal community. Mar Ecol Prog Ser 21:7-13

González HE (1992) Distribution and abundance of minipellets around the Antarctic peninsula. Implications for protistan feeding behaviour. Mar Ecol Prog Ser 90: $223-236$

Gordon DC Jr (1970) Some studies on the distribution and comparison of particulate organic carbon in the North Atlantic Ocean. Deep Sea Res 17:233-243

Hobson LA (1967) The seasonal and vertical distriburion of suspended particulate matter in an area of the Northeast Pacific Ocean. Limnol Oceanogr 12:642-649

Hoppe HG (1981) Blue-green algae agglomeration in surface water: a microbiotope of high bacterial activity. Kieler Meeresforsch (Sonderh) 5:291-303

Jacobsen TR, Azam F (1984) Role of bacteria in copepod fecal pellet decomposition: colonization, growth rates and mineralization. Bull mar Sci 35:495-502

Kane JE (1967) Organic aggregates in surface waters of the Ligurian Sea. Limnol Oceanogr 12:287-294

Kepkay PE, Johnson BD (1988) Microbial response to organic particle generation by surface coagulation in seawater Mar Ecol Prog Ser 48:193-198

Kepkay PE, Johnson BD (1989) Coagulation on bubbles allows microbial respiration of oceanic dissolved organic carbon. Nature 338:63-65

Koike I, Shigemitsu H, Kazuki T, Kazuhiro K (1990) Role of sub-micrometre particles in the ocean. Nature 345 $242-244$

Responsible Subject Editor: F. Azam, La Jolla, California, USA
Legendre L, Legendre P (1984) Ecologie numérique, Tome 2, La structure des données écologiques, 2 e edn. Masson. Paris, p 51-104

Linley EAS, Newell RC (1984) Estimates of bacterial growth yields based on plant detritus. Bull mar Sci 25(3):409-425

Longhurst AR, Koike l, Li WKW, Rodriguez J, Dickie P, Kepkay P, Partensky F, Bautısta B, Ruiz J, Wells M, Bird DF (1992) Sub-micron particles in northwest Atlantic shelf water. Deep Sea Res 39:1-7

Lorenzen CJ, Welschmeyer NA (1983) The in situ sinking rates of herbivore fecal pellets. J Plankton Res 6:929-933

Miquel JC, Fowler SW, La Rosa J, Buat-Menard P (1994) Dynamics of the downward flux of particles and carbon in the open northwestern Mediterranean Sea. Deep Sea Res $41(2): 243-261$

Mostajir B, Dolan JR, Rassoulzadegan F (1995) A simple method for the quantification of a class of labile marine pico- and nano-sized detritus: DAPI Yellow Particles (DYP). Aquat microb Ecol 9:259-266

Nagata T, Kirchman DL (1992) Release of macromolecular organic complexes by heterotrophic marine flagellates. Mar Ecol Prog Ser 83:233-240

Nöthig EM, von Bodungen B (1989) Occurrence and vertical flux of faecal pellets of probably protozoan origin in the southeastern Weddell Sea (Antarctica). Mar Ecol Prog Ser 56:281-289

Passow U, Alldredge AL (1994) Distribution, size and bacterlal colonization of transparent exopolymer particles (TEP) in the ocean. Mar Ecol Prog Ser 113:185-198

Pomeroy LR, Deibel D (1980) Aggregation of organic matter by pelagic tunicates. Limnol Oceanogr 25:643-652

Riley (jA (1963) Organic aggregates in seawater and dynamics of their formation and utilization. Limnol Oceanogr 8 : $372-381$

Riley GA (1970) Particulate organic matter in sea water. Adv mar Biol 8:1-11.8

Riley GA, Van Hemert D, Wangersky PJ (1965) Organic aggregates in surface and deep waters of the Sargasso Sea. Limnol Oceanogr 10:354-363

Riley GA, Wangersky PJ, Van Hemert D (1964) Organic aggregates in tropical and subtropical surface waters of the North Atlantic ocean. Limnol Oceanogr 9:546-550

SCOR (Scientific Committee on Oceanic Research)-UNESCO (United Nations Educational, Scientific, and Cultural Organization) (1964) Report of SCOR-UNESCO Working Group 17 on 'Determination of photosynthetic pigments' (Mimeograph). Sydney

Shanks AL, Trent JD (1980) Marine snow: sinking rates and potential role in vertical flux. Deep Sea Res 27A:137-143

Stoecker DK (1984) Particle production by planktonic ciliates Limnol Oceanogr 29(5):930-940

Sutcliffe WH, Edward Jr, Baylor R, Menzel DW (1963) Sea surface chemistry and Langmuir circulation. Deep Sea Res $10: 233-243$

Wells JT, Shanks AL (1987) Observations and geological significance of marine snow in a shallow water, partiallyenclosed marine embayment. J geophys Res 92 13185-13190

Wells ML, Goldberg ED (1993) Colloid aggregation in sea water. Mar Chem 41:353-358

Wells ML, Goldberg ED (1994) The distribution of colloids in the North Atlantic and Southern Oceans. Limnol Oceanogr 39(2):286-302

Manuscript first received: July 31, 1995

Revised version accepted: October 19, 1995 